\title{
EXPLORATION AND SCREENING FOR ENDOPHYTIC MICROBES OF MAIZE PLANT ROOT AGAINST Fusarium verticillioides
}

\author{
Rahmat Jahuddin $^{1}$, Jamila ${ }^{1}$, Awaluddin ${ }^{1}, \&$ Suriani $^{2}$ \\ ${ }^{1}$ Faculty of Agriculture Islamic University of Makassar, Indonesia \\ Jl. Perintis Kemerdekaan Km 9 No. 29 Makassar South Sulawesi \\ ${ }^{2}$ Indonesian Cereals Research Institute \\ Jl. Dr. Ratulangi No. 274 Maros South Sulawesi \\ E-mail: rahmatjahuddin@yahoo.co.id
}

\begin{abstract}
Exploration and screening for endophytic microbes of maize plant root against Fusarium verticillioides. Fusarium verticilloides is an important pathogen of maize which can attack cob and stem causing ear rot and stalk rot disease. Fusarium ear rot disease needs to get a serious attention because the mycotoxins produced by this pathogen very harmful for consumers. The aim of this study was to screen maize roots endophytic microbes as antagonist to $F$. verticilloides. Endophytes microbial exploration is done by taking samples of local roots of South Sulawesi and hybrid maizes in Soppeng Regency then isolated in Biological Laboratory of Islamic University of Makassar. The endophytes were then tested their effectiveness on inhibiting growth of mycelia pathogenic $F$. verticilloides by using dual culture method and tested the suppressing ability of $F$. verticilloides on maize seed and their influence on seed sprout length. The results showed that there were 8 endophytic microbes consisting of 4 isolates of the fungus group namely HS-01, HS-02, HS-04, LS-01 and 4 isolates from bacterial group namely HS-03, LS-02, LS-03, LS-04. While the results of microbial effectiveness testing on pathogenic F. verticilloides showed that HS-04 has the highest percentage of inhibition followed by isolate HS-01, HS-02 and LS-02. HS-04 isolate also showed the ability to suppress F. verticilloides attacks on corn seeds at $77.78 \%$. The highest seed sprout length was shown in LS-02 isolate application about $10.57 \mathrm{~cm}$. Thus it can be concluded that there were 3 potentially endophytic microbes to control the $F$. verticilloides namely HS-04, HS-01 and LS-02. The ability to stimulate plant growth became one of considerations to select these three microbes.
\end{abstract}

Key words: endofit microbes, Fusarium verticilloides, maize

\begin{abstract}
ABSTRAK
Eksplorasi dan skrining mikroba endofit perakaran tanaman jagung terhadap Fusarium verticillioides. Fusarium verticilloides merupakan patogen penting tanaman jagung karena yang menyerang tongkol dan batang menyebabkan penyakit busuk tongkol dan busuk batang.Penyakit busuk tongkol Fusarium perlu mendapatkan perhatian serius karena mikotoksin yang diproduksi patogen ini sangat berbahaya bagi konsumen. Penelitian ini bertujuan untuk skrining beberapa mikrobamikroba endofit perakaran jagung terhadap $F$. verticilloides. Eksplorasi mikroba endofit dilakukan dengan mengambil sampel perakaran jagung Lokal Sulawesi Selatan dan jagung hibrida di Kabupaten Soppeng kemudian diisolasi di Laboratorium Hayati Universitas Islam Makassar. Selanjutnya isolat mikroba endofit diuji efektivitasnya dalam menghambat pertumbuhan miselia patogen $F$. verticilloides dengan menggunakan metode dual culture. Pengujian lainnya yakni efektivitas mikroba dalam menekan serangan $F$. verticilloides pada benih jagung dan pengaruhnya terhadap panjang kecambah benih. Hasil eksplorasi didapatkan 8 jenis mikroba endofit yang terdiri dari 4 isolat golongan cendawan (HS-01, HS-02, HS-04, LS-01) dan 4 isolat dari golongan bakteri (HS-03, LS-02, LS-03, LS-04). Hasil pengujian efektivitas mikroba terhadap patogen $F$. verticilloides menunjukkan bahwa HS-04 memiliki persentase penghambatan tertinggi disusul isolat HS-01, HS-02 dan LS-02. Isolat HS-04 juga menunjukkan kemampuan menekan serangan $F$. verticilloides pada benih jagung paling tinggi sebesar $77,78 \%$. Panjang kecambah benih tertinggi ditunjukkan pada aplikasi isolat LS-02 sebesar 10,57 cm. Dengan demikian dapat disimpulkan bahwa terdapat 3 mikroba endofit yang potensi dikembangkan untuk pengendalian $F$. verticilloides yakni HS-04, HS-01 dan LS-02. Kemampuan merangsang pertumbuhan tanaman menjadi pertimbangan lain pemilihan ketiga mikroba tersebut.
\end{abstract}

Kata kunci: Fusarium verticilloides, jagung, mikroba endofit 


\section{INTRODUCTION}

Occasionally, corn cultivation experiences some main obstacles, including occurrence of plant pests which can reduce plant yields, even produce nonproducing plants. Some pathogens cause diseases on maize, they are including Peronosclerospora spp., Bipolaris maydis, Fusarium spp., Aspergillus spp., Puccinia spp., and Rhizoctonia solani. The pathogens infected the maize plants through any mediators, such as water, insects, air and soil. Fusarium spp. and $R$. solani were spread through soil, so that they are more recognized as soil borne pathogens (Muis et al., 2015; Suriani et al., 2015). Both pathogens are quite difficult to control because they can life, spread and survive long term in the soil. F. verticillioides can life in the soil for years, despite of unfavorable environment conditions and without host plant, by forming persistent spores such as chlamydospores (Sudantha, 2010).

The important thing to be wary about the infection of $F$. verticillioides is its capability to produce a mycotoxin (Djaenuddin \& Muis, 2013). Some types of toxins produced by $F$. verticillioides are fusaric acid, fusarin, gibberellin, moniliformin and fumonisin. Especially in maize seeds, it is noticed that the fungi producing fumonisin is correlated to the pathogen biomass. The toxin is produced most at high oxygen pressure and low $\mathrm{pH}$. Therefore, the outbreak of $F$. verticillioides on maize plant must be prevented because it can produce poisons to human and livestock animals. Fumonisin causes necrosis of brain tissues (leucoencephalomalacia $=$ LEM) in horses. Other than that, the fumonisin B1 was also reported as toxic to central nervous system, liver, pancreas, kidney and respiratory tracts in some other species of animals (Widiastuti, 2006).

The production of chlamydospores by $F$. verticilloides can endure long in soil where the dead host plant existed, and it causes difficulty in pathogen controlling. Reduction in chlamydospores population as initial inoculum is one of appropriated methods of controlling. The application of systemic fungicide can reduce the chlamydospore population through improving plant tenacity, and therefore, resulting healthy seeds (Kristiawati et al., 2014). Another controlling method is by using antagonistic microbes which have capabilities to induce plant endurance. The bacteria Bacillus spp. and Pseudomonas spp. were known to have capabilities in inducing plant tenacity against pathogen outbreak (McMilan, 2007; Djaenuddin, 2016). These microbes can be found from some sites, either in plant rhizosphere or as endophytic microbes in plant.
The endophytic microbes are plant tissueassociating microorganisms without negative impact to the plant. The endophytic microbes can be found in plant root, stem, and leaves. The microbes produce bioactive compound acting as an anti-microbe that is used either in agriculture, industrial or health sector. The microbes were mostly from fungi groups producing secondary metabolite compounds with anti-microbial properties (Strobel, 2003).

The role of endophytic microbes as biological controlling agent of plant has been proved by many researchers. The endophytic microbes have been discovered from particular parts of plant and they have been developed as antagonistic pathogens. Marwan et al. (2011) have found 4 endophytic microbial isolates (EAL15, EKK10, EKK20, EKK22) of banana plant root that have capability to suppress blood disease occurrence on banana plantation. Hutabalian et al. (2015) reported that the endophytic fungi isolated from barangan banana plant root (Pulluria sp.) capable to inhibit $F$. oxysporum growth. The other researchers, Saylendra \& Firnia (2013) have found two genera of bacteria from maize plant root identified as Bacillus sp. and Pseudomonas sp. Developing the endophytic microbes as biological control agent is an excellent opportunity. Based on those facts, we are interested to explore the endophytic microbes from maize plant root, to select its effectiveness in inhibiting development of soil borne pathogens of maize plants, especially $F$. verticilloides.

\section{MATERIALS AND METHODS}

Research Site. The research was conducted on maize root samples taken from farming fields at Soppeng regency. The research steps from exploration to microbial effectiveness assay was conducted at Laboratory of Biology, Faculty of Agricultural, Universitas Islam Makassar, from April to Oktober 2017.

Exploration of Endophytic Microbes. Samples of hybrid and local maize plant roots of South Sulawesi (jagung pulut putih) were obtained from farming field at Soppeng regency. Root samples were taken from healthy, well growing, and pest and pathogen-free plants. The root endophytic microbes were isolated firstly by cutting the root samples in small pieces and sterilizing them by soaking in aquadest for 3-5 minutes. The samples were then removed and soaked in $70 \%$ alcohol for 1-3 minutes, and they were finally removed and soaked back in aquadest for 3-5 minutes. The root pieces were grown on PDA (Difco ${ }^{\mathrm{TM}}$ Potato Dekstrose Agar) and NA (Difco ${ }^{\mathrm{TM}}$ Nutrient agar), then were incubated 
for 3-4 days in room temperature $\left(28-30{ }^{\circ} \mathrm{C}\right)$. The growing fungi inoculum was individually isolated on new PDA media, and the growing bacteria was grown on new NA media, then they were incubated for 7 days.

Preparation of Fusarium verticilloide Isolates. The fungi inoculum $F$. verticilloides was isolated from corncob with indication of cob rot disease. The kernels infected by $F$. verticilloides were sterilized for 1 minute in aquadest, $70 \%$ alcohol, then aquadest respectively, and then were grown on PDA media. The growing mycelia of $F$. verticilloides were isolated on new PDA media on petri-dish, then were incubated for 14 days in room temperature $\left(28-30^{\circ} \mathrm{C}\right)$. Identification of pure isolates on media was achieved by characterizing morphological properties of $F$. verticilloides by means of the identification keys by Quimio \& Hanlin (1999).

\section{Assay for Inhibition Effectiveness of Endophytic} Microbes on F. verticilloides Mycelial Growth. The endophytic microbes of maize root were examined for their antagonistic properties against $F$. verticilloides in vitro by using dual culture method. The examination was performed by using completely randomized design with 9 treatments and 7 repetitions. Eight isolates of endophytic microbes were obtained, they are consisted of 4 fungi isolates (HS-01, HS-02, HS-04, LS-01) and 4 bacteria isolates (HS-03, LS-02, LS-03, LS-04). The $F$. verticilloides grown on petri-dish without any endophytic microbes was used as control.

The effectiveness test of endophytic fungi was performed on PDA media which is prepared aseptically with standard sterilization by using autoclave at $121^{\circ} \mathrm{C}$ for 15 minutes. Ten milliliters media were poured on 9 $\mathrm{cm}$ diameter petri dish and allowed to solidify. The petri dish was then scaled and divided into two sides. On one side, the endophytic microbe was inoculated and on the other side for $F$. verticilloides. The cultures were incubated for 7 days in a room with half day illumination (12 hours lightsome and 12 hours dark). On the other side, the assay for endophytic bacteria was completed by using $10 \mathrm{ml} \mathrm{NA}$ poured on petri dish and allowed to solidify. Furthermore, the fungi $F$. verticilloides was put on the center of petri dish, and the endophytic bacteria was streaked on 4 points around the $F$. verticilloides inoculum (Figure 1). The cultures were incubated for 7 days in a room with 12 hours lighted and 12 hours dark.

Antagonistic effect of endophytic microbes on $F$. verticilloides was noticed by measuring the PIRG (percentage inhibition of radial growth) (Singh \& Vijay 2011)

$$
\text { PIGR (\%) }=\frac{R 1-R 2}{R 1} \times 100 \%
$$

PIRG $=$ Percentage inhibition of radial growth $(\%$ inhibition);

R1 = Diameter of pathogen without the antagonistic isolate (control);

R2 = Diameter of pathogen with the antagonistic isolate (dual culture)

The Effectiveness of Endophytic Microbes in Suppressing $F$. verticilloides Outbreak on maize seedling. The assay was performed at UIM Biological Laboratorium by making the maize seedlings grow with ISTA method (2006), i.e. the seedlings were grown on wet paper media with a plastic at base lining. The research was arranged based on a Complete Randomized Design with 9 treatments and 3 replicas. The treatments consisted of 8 seed treatments with individually immersion in endophytic microbe suspension and a control (seed with the only immersion in F. verticilloides suspension). Before the test, the endophytic microbe suspensions were prepared by

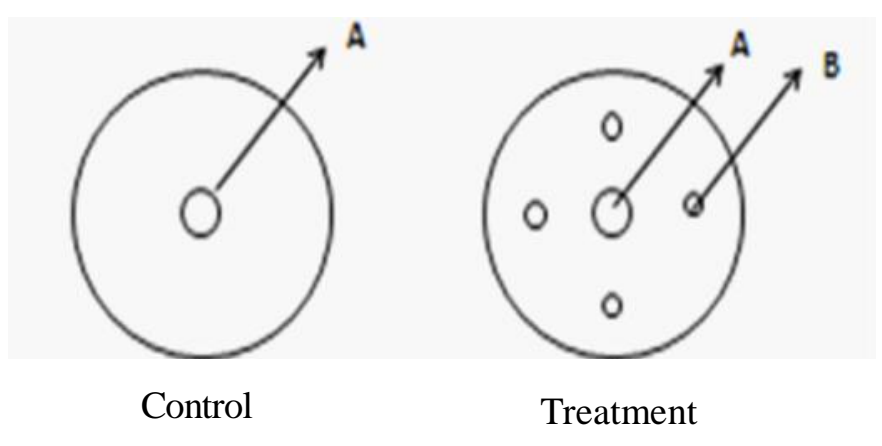

Figure 1. (A) : F. verticilloides. (B): Endophytic bacteria. 
adding $10 \mathrm{ml}$ aquadest into petri dish containing 15 days growing endophytic microbes. Colonies of each endophytic fungi were counted by using a haemocytometer, by using suspension with $10^{6} \mathrm{cfu} / \mathrm{ml}$ conidia density. Bacterial suspension, on the other hand, has $10^{9}-10^{10} \mathrm{cfu} / \mathrm{ml}$ density, which are counted by using colony counter and the following formula (Waluyo, 2008):

\section{CFU's $/ \mathrm{ml}=$ colony number $\mathrm{x}$ dilution factor}

The assay using corn seeds from Anoman variety was performed by immersing the seeds in a suspension of $F$. verticilloides for 2 hours. Furthermore, the seeds were left dried and then subjected to each immersion treatment in endophytic microbe suspension for 2 hours. Every 30 seeds from each test unit were grown on paper media and incubated for 7 days.

Observed variables including the percentage of seedlings infected by F. verticilloides and the length of sprout (in $\mathrm{cm}$ ) which is measured on the $7^{\text {th }}$ day after planted. Percentage of $F$. verticilloides infection was measured by using the following formula:

$$
\mathrm{I}=\frac{\mathrm{A}}{\mathrm{B}} \times 100 \%
$$

I $=$ Percentage of $F$. verticilloides infection

$A=$ Number of seeds infected by $F$. verticilloides

$\mathrm{B}=$ Number of germinating seeds

Resulted data was analized by varian analysis and an advanced test using Duncan's New Multiple Range Test (DNMRT) by 5\% level.

\section{RESULTS AND DISCUSSION}

Exploration of Endophytic Microbes. The exploration of endophytic microbes on local corn plant (South Sulawesi) and hybrid corn obtained 8 root associated-endophytic microbes (Table 1). They are consisted of 4 endophytic microbes from fungi groups and the rest are from bacteria groups.

Effectiveness of Endophytic Microbe in Suppressing Mycelial Growth of $\boldsymbol{F}$. verticilloides. Results of the effectiveness test of inhibitory properties of the 8 endophytic microbes on mycelial growth of $F$. verticilloides by using dual culture method showed that there is an isolate of endophytic microbe, that is HS-04, that has an effective inhibition with significant difference to all other isolates. The other isolates showed inhibition capability on mycelial growth of $F$. verticilloides more than $30 \%$, they are LS-02, HS-01 and HS-02 with inhibitory percentage $40,2 \% ; 34,88 \%$ and $34,16 \%$, respectively (Table 2 ).

Mechanism of inhibition by endophytic microbes on mycelial growth of $F$. verticilloides was showed in Figure 2 . The $F$. verticilloides paired with endophytic microbe LS-02 and HS-01 was noticeably showed imperfect mycelial growth compared to the control (single growth of $F$. verticilloides on petri dish). The controlling mechanism of the endophytic microbes on pathogen growth are occurred through competition and secondary metabolite release. The interaction between the endophytic microbes and pathogens can lead to pathogen hypha cleared up, as a result of utilization of pathogen content as nutrition by endophytic microbes

Table 1. Microbes explored from plant roots of local (South Sulawesi) corn and hybrid corn of Soppeng regency

\begin{tabular}{cccc}
\hline Isolate code & Origin & Microbe group & Colony color \\
\hline HS-01 & Hybrid corn plant root & Fungi & Nigrescent white \\
HS-02 & Hybrid corn plant root & Fungi & Brownish white \\
HS-03 & Hybrid corn plant root & Bacteria & Clear white \\
HS-04 & Hybrid corn plant root & Fungi & Dark green \\
LS-01 & Local corn plant root & Fungi & Nigrescent white \\
LS-02 & Local corn plant root & Bacteria & Opaque white \\
LS-03 & Local corn plant root & Bacteria & Opaque white \\
LS-04 & Local corn plant root & Bacteria & Opaque white \\
\hline
\end{tabular}


(Nurzannah et al., 2014). Furthermore, Sunarwati \& Yoza (2010) stated that the interaction between pathogen hypha and the antagonistic organisms is characterized with clearing off the pathogen hypha because of the cell content utilization as nutrition by controlling organisms. Furthermore, the endophytic microbes can make the pathogen hypha shrink, as discovered by Kurnia et al. (2014).

The differences in inhibitory capability on mycelial growth of $F$. verticilloides indicated differences in bioactive compounds resulted by each endophytic microbe. Therefore, a further research on antibiotic contents of effective microbes is needed to conduct. The larger the inhibitory zones, the larger the antifungal activity. The endophytic microorganisms can produce bioactive compounds other than contained compounds in their host plants (Pratiwi, 2008).
Effectiveness of Endophytic Microbes in Suppressing $\boldsymbol{F}$. verticilloides Infection In Vitro. The results showed that seeds immersed in suspension of endophytic microbe isolate HS-04 has the weakest attacks percentage of $22,22 \%$ (Table 3 ). The other isolates have insignificant difference of attacks percentage from the isolate HS-04, they are the isolate HS-03, LS-02 and LS-04 with onset percentage of $44,44 \%, 57,78 \%$, and $60 \%$, respectively.

The inhibition effectiveness of endophytic microbes from fungi group on Fusarium spp in vitro was proved by Orole \& Adejumo (2009). Their research indicated that 5 endophytic fungi isolated from maize roots provided inhibition to development of damping off disease on maize plants caused by Fusarium spp. and an endophytic fungi, Alternaria alternate, showed the highest inhibition, from 53 to $80 \%$. The inhibition

Table 2. Inhibition percentage of the endophytic microbes of maize plant root on mycelial growth of $F$. verticilloides

\begin{tabular}{cc}
\hline Endophytic microbes & Inhibition percentage on mycelial growth of $F$. verticilloides \\
\hline HS-01 & $34.88 \mathrm{~b}$ \\
HS-02 & $34.16 \mathrm{~b}$ \\
HS-03 & $0 \mathrm{c}$ \\
HS-04 & $58.42 \mathrm{a}$ \\
LS-01 & $24.25 \mathrm{~b}$ \\
LS-02 & $40.20 \mathrm{~b}$ \\
LS-03 & $0 \mathrm{c}$ \\
LS-04 & $5.04 \mathrm{c}$ \\
\hline
\end{tabular}

Number in one column followed by the same letter (s) was not significantly different based on Duncan's New Multiple Range Test (DNMRT) test at 5\% of significant level.
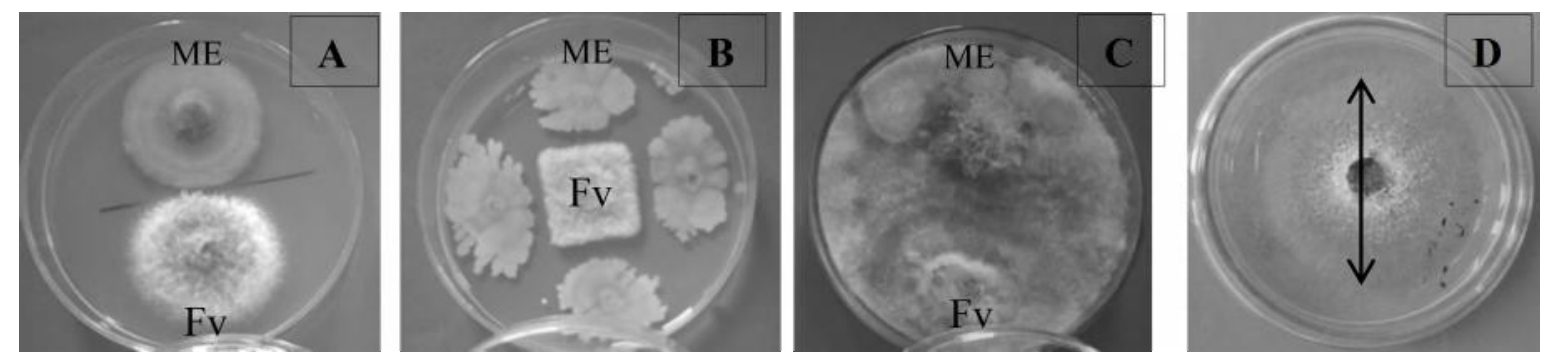

Figure 2. Inhibition test of endophytic microbes on mycelial growth of F.verticilloides on the $7^{\text {th }}$ day after inoculation. (A) Endophytic microbe LS-01 on pathogen F.verticilloides; (B) Endophytic microbe LS-02 on pathogen F.verticilloides: (C) Endophytic microbe HS-01 on pathogen F.verticilloides; (D) Single mycelial growth of F.verticilloides on petri dish at the $7^{\text {th }}$ day after inoculation. 
capability was predicted due to the endophytic microbe's capacity to induce tenacity in maize plant. Tenacity induction in plants is a phenomenon when there is improvement of plant tenacity on pathogen infection as a response to stimulation. The tenacity is a plant protection based on tenacity mechanisms stimulated by metabolic changes. Moreover, competition in the same niche between pathogen and the endophyte can also lowering the infection rate. For example, the endophytic bacteria will be closely related to or influenced by bacterial density, colonization level, and the site of bacteria in relation to pathogen feeding location (Harni et al., 2012).

The effect of endophytic microbes on maize plant growth. Observation on sprout length indicated that the seeds surrounded by endophytic microbe isolate LS-02 has the longest sprout with length $10,57 \mathrm{~cm}$ and they are significantly different to the control (Table 4). However, on the whole, seeds those are immersed in endophytic microbe suspension have longer sprouts compared to the control.

Differences in length of maize sprouts between treated seeds and control demonstrate that the endophytic microbes produce growth inducingcompounds. It is corresponding to the research by Munif et al. (2015) that showed that half of 10 endophytic bacterial isolates capable to improve tomato plant height by 30 minutes seed treatment. Additionally, immersion treatment on pepper seedling root with some endophytic bacteria isolated from pepper plant has shown to improve root weight and plant crown on pepper plants (Munif \& Harni, 2011; Harni \& Ibrahim, 2011). The improvement in plant growth is predicted caused by the endhophyt bacteria can produce IAA (Ramadhan et al. 2017). And then the endophytic bacteria merging into some

Table 3. Percentage of the F. verticilloides attacks on corn seeds on 7 day after plant

\begin{tabular}{cc}
\hline Endophytic Microbes & Percentage of the $F$. verticilloides attacks $(\%)$ \\
\hline HS-01 & $67.78 \mathrm{ab}$ \\
HS-02 & $73.33 \mathrm{ab}$ \\
HS-03 & $44.44 \mathrm{bc}$ \\
HS-04 & $22.22 \mathrm{c}$ \\
LS-01 & $61.11 \mathrm{ab}$ \\
LS-02 & $57.78 \mathrm{abc}$ \\
LS-03 & $70.00 \mathrm{ab}$ \\
LS-04 & $60.00 \mathrm{abc}$ \\
Kontrol & $94.44 \mathrm{a}$ \\
\hline
\end{tabular}

Number in one column followed by the same letter (s) was not significantly different based on Duncan's New Multiple Range Test (DNMRT) test at $5 \%$ of significant level.

Table 4. The length of sprouts grown on plastic rolled-paper on 7 days after plant

\begin{tabular}{cc}
\hline Endophytic Microbes & The length of sprouts grown \\
\hline HS-01 & $8.07 \mathrm{ab}$ \\
HS-02 & $8.25 \mathrm{ab}$ \\
HS-03 & $8.28 \mathrm{ab}$ \\
HS-04 & $7.17 \mathrm{ab}$ \\
LS-01 & $9.15 \mathrm{ab}$ \\
LS-02 & $10.57 \mathrm{a}$ \\
LS-03 & $8.33 \mathrm{ab}$ \\
LS-04 & $9.88 \mathrm{a}$ \\
Kontrol & $4.96 \mathrm{~b}$ \\
\hline
\end{tabular}

Number in one column followed by the same letter (s) was not significantly different based on Duncan's New Multiple Range Test (DNMRT) test at $5 \%$ of significant level. 
physiological processes in plant by means of introducing IAA they produce to the plant, making the plant more sensitive in changing the endogenic IAA concentration with the result that it supports lateral root and adventive root forming and primary root elongation (Leveau \& Lindow, 2005).

\section{CONCLUSION}

The exploration of endophytic microbes from hybrid and local (South Sulawesi) maize plant roots of Soppeng regency resulted 8 endophytic microbe isolates, consisting of 4 fungi (HS-01, HS-02, HS-04, LS-01) and 4 bacteria (HS-03, LS-02, LS-03, LS-04). The test results showed that there are 3 potential endophytic microbes to develop as biological controlling agents against $F$. verticilloides, they are isolate HS-04, HS-01 and LS-02. Their capability in inducing plant growth also becomes a consideration in selecting the three isolates.

\section{ACKNOWLEDGMENTS}

On this occasion the authors would like to thank the part of DP2M Ristekdikti who have funded this research in 2017. And we would like to thank all participant who help our research.

\section{REFERENCES}

Djaenuddin N \& Muis A. 2013. Uji patogenitas Fusarium moniliforme Sheldon pada jagung. In: Muis A, Pabbage MS, Yasin M, Aqil M, Hermanto, \& Pakki S (Eds). Prosiding Seminar Nasional Serealia, Meningkatkan Peran penelitian Serealia Menuju Pertanian Bioindustri. Pp. 438-442. Balai Penelitian Tanaman Serealia, Maros. June 18, 2013.

Djanenuddin N. 2016. Interaksi bakteri antagonis dengan tanaman: ketahanan terinduksi pada tanaman jagung. Iptek Tanaman Pangan 11(2): 143-148.

Harni R \& Ibrahim MSD. 2011. Potensi bakteri endofit menginduksi ketahanan tanaman lada terhadap infeksi Meloidogyne incognita. J. Littri 17(3): 118-123.

Harni R, Supramana, Sinaga MS, Giyanto, \& Supriadi. 2012. Mekanisme bakteri endofit mengendalikan nematoda Pratylenchus brachyurus pada tanaman nilam. Bul. Littro. 23(1): 102-114.
Hutabalian M, Pinem MI, \& Oemry S. 2015. Uji antagonisme beberapa jamur saprofit dan endofit dari tanaman pisang terhadap Fusarium oxysforum f.sp. cubens di laboratorium. $J$. Agroteknologi 3(2): 687-695.

ISTA. 2006. International Rules for Seed Testing. International Seed Testing Association, Switzerland.

Kurnia AT, Pinem MI, \& Oemry S. 2014. Penggunaan jamur endofit untuk mengendalikan Fusarium oxysforum f.sp. capsici dan Alternaria solani secara in vitro. J. Agroteknologi 2 (4): 15961606.

Kristiawati Y, Sumardiyono C, \& Wibowo A. 2014. Uji pengendalian penyakit layu Fusarium pisang (Fusarium oxysporum f.sp. cubense) dengan asam fosfit dan aluminium-fosetil. $J$. Perlindungan Tanaman Indonesia 18(2): 103110.

Leveau JH \& Lindow SE. 2005. Utilization of plant hormone indole-3-acetic acid for growth by Pseudomonas putida strain 1290. Appl. Environ. Microbiol. 71(5): 2365-2371.

Marwan H, Sinaga MS, Giyanto, \& Nawangsih AA. 2011. Isolasi dan seleksi bakteri endofit untuk pengendalian penyakit darah pada tanaman pisang. J. HPT Tropika 11(2): 113-121.

McMilan S. 2007. Promoting growth with PGPR. The Canadian Organic Grower. Soil Foodweb Canada Ltd. Soil Biology Lab. \& Learning Centre. Pp. 3-34.

Muis A, Djaenuddin N, \& Nonci N. 2015. Evaluasi lima jenis inner carrier dan formulasi Bacillus subtilis untuk pengendalian hawar pelepah jagung (Rhizoctonia solani Kuhn). J. HPT Tropika 15 (2): 164-169.

Munif A \& Harni A. 2011. Potensi bakteri endofit dan rhizosfer dalam meningkatkan pertumbuhan jagung. In: Makarim K, Zubachtirodin, Yasin HG, Soenartiningsih, Dahlan HA, Tandiabang J, Arief R, Suarni, Hermanto, \& Aqil M (Eds). Prosiding Seminar Nasional Serealia, Inovasi Teknologi Mendukung Swasembada Jagung dalam Diversifikasi Pangan: pp 1-8. Balai Penelitian Tanaman Serealia, Maros. October 3-4, 2011. 
Munif A, AR Wibowo, \& EN Herliyana. 2015. Bakteri endofit dari tanaman kehutanan sebagai pemicu pertumbuhan tanaman tomat dan agens pengendali Meloidogyne sp. J. Fitopatologi Indonesia 11(6): 179-186.

Nurzannah SE, Lisnawita, \& Bakti D. 2014. Potensi jamur endofit asal cabai sebagai agens hayati untuk mengendalikan layu Fusarium (Fusarium oxysforum) pada tanaman cabai dan interaksinya. J. Agroteknologi 2(3): 1230-1238.

Orole OO \& Adejumoo TO. 2009. Activity of fungal endophytes against four maize wilt pathogens. Afr. J. Microbiol. Res. 3(12): 969-973.

Pratiwi ST. 2008. Mikrobiologi Farmasi. Erlangga, Jakarta.

Quimio TH \& Hanlin RT. 1999. Illustrated Genera and Species of Plant Pathogenic Fungi in the Tropics. College of Agriculture Publication Program. Philippines.

Ramadhan AR, Oedjijono, \& Hastuti RD. 2017. Efektivitas bakteri endofit dan penambahan Indole Acetic Acid (IAA) dlam meningkatkan pertumbuhan tanaman padi Oryza sativa L. Scripta Biologica 4(3): 171-181.

Saylendra A \& Firnia D. 2013. Bacillus sp. dan Pseudomonas sp. asal endofit akar yang berpotensi sebagai pemacu pertumbuhan tanaman. J. Ilmu Pertanian dan Perikanan 2 (1): 19-27.

Sing PK \& Vijay K. 2011. Biological control of Fusarium wilt of Chrysanthemum with Trichoderma and Botanicals. J. Agric. Techn. 7(6): 1603-1613.
Strobel GA. 2003. Endophytes as sources of bioactive products. J. Microbes Infect 5(6): 535-544.

Sudantha IM. 2010. Pengujian beberapa jenis jamur endofit dan saprofit Trichoderma spp. terhadap penyakit layu fusarium pada tanaman kedelai. Agroteksos 20 (2-3): 90-102.

Sunarwati D \& Yoza R. 2010. Kemampuan Trichoderma dan Penicillium dalam menghambat pertumbuhan cendawan penyebab penyakit busuk akar durian (Phytophthora palmivora) secara in vitro. Prosiding Seminar Nasional Program dan Strategi Pengembangan Buah Nusantara. pp 176-189. Balai Penelitian Tanaman Buah, Solok.

Suriani, Muis A, \& Aminah. 2015. Efektivitas 8 formulasi Bacillus subtilis dalam menekan pertumbuhan Fusarium moniliforme secara in vitro. Pp. 428435. Dalam: Muis A, Syafruddin, Aqil M, \& Bahtiar (Eds). Prosiding Seminar Nasional Serealia. Maros: Pusat Penelitian dan Pengembangan Tanaman Pangan.

Waluyo L. 2008. Teknik Metode Dasar Mikrobiologi. Universitas Muhamadiyah Malang Press. Malang.

Widiastuti R. 2006. Mikotoksin: pengaruh terhadap kesehatan ternak dan residunya dalam produk ternak serta pengendaliannya. Wartazoa 16(3): 116-127. 